\title{
Using Student Created Video Presentations to Build Experiential Learning in the Oral EFL Presentation Classroom
}

\author{
Natalie Hallemans \\ Associate Professor, Dankook University, 12070328@dankook.ac.kr
}

\section{Abstract}

This qualitative study investigates the learning experiences of students in an online oral presentation class where both course delivery, presentation assignments and exams were recorded submissions uploaded to an online classroom. The objective of this study is to understand if the constructivist format of the class encouraged Kolb's experiential learning environment and to garner any positive or negative takeaways from the experience. Data collected revealed that most students spent 1-2 hours preparing for their presentations and an additional 1-2 hours recording. The additional time spent recording alluded to the idea that recorded submissions directly impacted student motivation to improve. It was also determined that most students preferred recorded submissions because they provided an opportunity to self-reflect and correct mistakes and released them from the anxiety of performing before a live audience thus enhancing the constructivist classroom environment. While many researchers believe that oral presentations are best practiced before a live audience where the skills are normally used, in the post-COVID work environment, more people are expected to work remotely and will require online oral presentation proficiencies. Developing the skills required to deliver asynchronous presentations will make students more competitive in the job market.

Key Words: online education, oral EFL presentations, experiential learning, motivation, reflective learning

1. Introduction

2. Literature Review

3. Methodology

4. Findings and

Discussions

5. Conclusions, Implications and Limitations 


\section{Introduction}

2020 was an interesting year for education. Mobility restrictions resulting from a widespread pandemic forced educational institutions around the globe to contend with moving classes to an online format. Courses that were designed to be taught in person had to be redeveloped to adapt to a distance learning environment. For some subjects, the conversion to online teaching and learning was simple, but for others, the reality of the new educational environment was more challenging to roll out. This author was tasked with teaching oral presentation skills to English as a Foreign Language (EFL) learners online at a university in South Korea.

Oral presentations are generally accepted as a key component of EFL programs, particularly in a communicative language teaching classroom (Al-Issa \& Al-Qubtan, 2010). When preparing for and delivering an oral presentation, students use the four basic skills of listening, speaking, reading and writing all skills that develop their communicative competence (Al-Issa, 2006). In an offline classroom environment, the purpose of the oral presentation course is to among other things, to encourage second language learners to build their confidence in the command of the target language, while addressing their fears of public speaking. It is generally accepted that to become a better public speaker, one needs to practice in the environment they will be using the skills. That is, in front of a live audience. However, in an online classroom, the critical component of a live, in-person audience is missing. This does not mean you cannot improve your oral presentation skills through an online class, but rather there is just insufficient literature available on the experience. This is likely because according to Böhme (2009), experts in the EFL teaching field believe that oral presentation skills can only be improved by practicing in "learning environments which closely resemble the situations in which the acquired skill is actually applied and performed" (p. 1). As a result, when the course is offered online, it tends to be a hybrid format with lessons available electronically and homework presentations and exams performed in person before a live audience.

Given the necessity of distance learning under the pressure of COVID-19, if students were to benefit from the class at all, a delivery method for the class and its associated assignments and exams, had to be selected that would provide an adequate self-directed and communicative learning experience. The online environment provided an excellent opportunity to offer a constructivist classroom, testing Kolb's experiential learning theory, where students learn by a process of experiencing, reflecting, thinking and acting (McLeod, 2017). Classes were taught asynchronously through pre-recorded lessons uploaded to the university's portal LMS system and student assignments consisted of 5 pre-recorded homework presentations and 2 pre-recorded exam presentations, over a 15 -week period, submitted to the online classroom portal for review and assessment.

This study was conducted to investigate the following questions: 1) How does a constructivist design affect experiential learning in an online EFL oral presentation classroom? and 2) How does this type of classroom impact the students' learning experience of oral EFL presentation skills? More specifically, their personal comfort, self-confidence and motivation in the assignment and exam process, as well as their workload resulting from the greater amount self directed learning was examined. Overall, the goal is to appreciate how oral EFL presentation classes can be improved in the future, in both online and in offline, in-person classrooms.

\section{Literature Review}

\subsection{Oral Presentation Education}

Oral presentations are a well-established component of EFL education. Whether students are required to make English presentations in their future careers or not, the process of researching and writing a script, practicing, 
and delivering content helps promote all aspects of the language's mastery, with a special focus on speaking. More specifically, oral presentations help develop communicative competence by guiding students from a simple language study to effective language use (King, 2002). Moreover, student presentations help the learner develop an awareness of their own communication skills by providing them with ample opportunities to practice (Živković, 2014). Oral presentations are a student-centered activity where the design, practice and delivery are all organized and modified by the student who takes charge of their learning experience and outcome (Al-Issa \& Al-Qubtan, 2010).

However, researchers have long questioned the role anxiety plays in motivation for a student to learn, particularly when it comes to oral presentations in EFL education. Katchen (1991) and King (2002) argue that oral presentations might not appropriately reflect a student's mastery of the language. This is because many other factors impact the delivery outcome of a presentation before a live audience. According to Katchen, East Asian students are wary of public speaking activities in English (1991). As a result, their nervousness causes them to stumble through their presentations often not adequately reflecting their skills. She wrote, "These students' main concern is surviving the ordeal, not improving their speaking skills" (p. 531).

In other words, students can be proficient enough speakers, but collapse under the pressure of a live audience, unable to deliver even the most prepared speech. Research on the topic reveals the key factors that influence the success of a foreign language learner. Al-Hebaish (2012), cites several studies that show a positive relationship between self-confidence and second language acquisition success. His research ties the confidence levels of female English language majors in Saudi Arabia to their success in oral presentations. He found that the more self-confident the student, the better they performed in oral presentations. Conversely students with an absence of self-confidence, demonstrated little motivation to earn good results in their oral presentations. Part of his conclusion revealed it was important for the instructor to foster a learning environment that boosts the students' self-confidence.

Fook, Sidhu, Rani, and Aziz (2011) also showed that successful presentations can be related to self-confidence and the ability to manage anxiety. They explored several studies that showed a significant negative relationship between anxiety and success in a target foreign language. They also highlighted the role that a student's attitude towards learning the target language plays in a language learner's success.

Gardner (2007), a proponent of motivation and second language acquisition, highlighted that unlike the first language which is apparently acquired with ease, learning a second language may not seem an absolute necessity hence requires a significant amount of motivation. Motivation can be influenced by several factors and among the factors are anxiety and attitude towards the learning environment (Fook, Sidhu, Rani, \& Aziz, 2011, p. 32).

Therefore, a positive attitude towards mastering the target language automatically generates motivation to learn more and retain that learning. To generate that positive attitude, the instructor must create a learning environment that is as encouraging as possible (Fook et al., 2011). The problem is, no matter how comfortable a learning environment can be, oral presentations before a live audience may always remain a source of extreme anxiety in any language for some people. King (2002) pointed out that oral presentations contradict the principles of language teaching as they increase student anxiety when they should be lowering it. "Oral presentations can be a face-threatening activity, particularly for some Asian students” (King, 2002, p. 404).

Even before the global pandemic forced the majority of classes online, the increased reliance on technology in the learning environment meant that more and more 
classes were being offered over the Internet because of their time and space advantages. This translated to increased opportunities for greater student-centred self-directed learning, skills critical for a $4^{\text {th }}$ industrial revolution economy. Online oral EFL presentation classes were also created, however, their study remains fragmented and limited to hybrid courses where the lessons were delivered asynchronously, while the student presentations assignments were delivered before a live audience environment. Böhme, (2009), Smirnova and Nuzha (2013) agreed that it was possible to teach and learn oral presentations in an online environment, but they also stipulated that the course needed a hybrid element, so that students still had a chance to deliver their presentations before a live audience. They both stated this was critical for the learning experience.

The efficacy of learning oral presentation skills online using student created presentation videos needs more investigation, however early reports have indicated interesting yet consistent results. Saidalvi and Mansor (2012) conducted research on a fully online oral presentations classroom and found that students preferred recorded deliveries of oral presentations as they eliminated their fear of presenting before a live audience and they had a lot of opportunities to practice their speeches. Their study revealed that $51.9 \%$ of the students agreed and $44.4 \%$ strongly agreed that recorded presentations eliminated their fear of public speaking. $48.1 \%$ also agreed and another $48.1 \%$ strongly agreed that recorded presentations offered students several opportunities to practice delivering their speeches.

\subsection{Constructivist Based Learning Using Technology in Oral Presentations}

Oral presentations are a student-centred activity. Instead of the traditional top-down teaching of some language classrooms, oral presentations place the responsibility for production in the hands of the student. They take charge of researching, writing, practicing, and delivering their speech. In this situation, the teacher acts as a "guide, organizer, consultant, resource person, and supporter" (King, 2002, p. 407). With much of this learning landing on the shoulders of the student, one method that has been proposed to help address performance related anxiety is to have students record and review their presentations. Katchen (1991) discussed this idea when VHS videos were being adapted for use in the classroom. The benefits purported were the ability to self-reflect and auto-correct skills where necessary. She reported that by using recordings for presentations, students were able to reflect on their own fluency, learning where they needed to improve and helped them self-correct. "Because they are preparing something tangible, producing a product they can see, most practice harder to put on a good performance. Students can learn to become more self-critical. They can see their problems and chart their improvement" (1991). Self assessment is critical in education. It helps students put their knowledge into practice, a skill set that will transfer well into post educational environments.

Arguably, by introducing self-produced recordings to the oral EFL presentation classroom, the teacher is adding to the constructivist learning environment where students construct knowledge through their personal learning experiences. Technology helps students become even more responsible for their own experiential learning outcome. It enables students to be more responsible and active in their learning experience and active learners develop by "constructing new knowledge based upon their prior knowledge through the interaction with the environment" (Živković \& Stojkoviý, 2013, p. 74).

In a traditional live audience presentation classroom, students are tasked with researching, writing, and delivering their presentations. However, their delivery is a "one and done" situation, where the students present to merely get through or survive the experience. In some cases, students can be asked to reflect on their performance to highlight areas they felt were well done and others that needed improving. The benefits of reflection are key to the learning process. Smirnova \& Nuzha (2013) wrote, 
According to Kolb's (1984) theory, having an experience is insufficient to progress in studies. It is necessary to reflect on the experience, gain understanding of the concepts engaged in the experience, and later test the concepts in a new situation. This is the way to continuously transform information into knowledge and for practical skills to be applied in a number of meaningful situations (p. 410)

Students using technology to prepare recorded presentations create a self-reflection process by default, as it provides them with a tool to help think critically about their own work, error correct and produce new and improved output. Thus, it creates a true constructivis learning experience that Katchen first proposed in 1991 and an experiential learning environment that Kolb views as key in the process of developing knowledge.

Researchers in education, with the $4^{\text {th }}$ industrial revolution economy in mind, argue teachers are expected to use technology to promote this student-centered approach to learning. The goal is to develop students ready to become workers in this digitized economy that can independently control and monitor their own work (Mohd \& Ismail, 2020).

Spöttl and Windelband (2021) argue that while it is clear more educational training needs to be developed to better prepare students for this new digital economy, very little has been done to develop appropriate curriculums to achieve this objective. Students need to be adept in the skills required for an increasingly digitised workplace. Mohd and Ismail (2020) wrote that for the language and education industry to remain relevant in the new economy, universities will have to "change their curriculum and delivery to ensure that their graduates have jobs" (p.6).

Using technology to record oral presentations can reduce student anxiety, which increases their motivation, while the ability to self-correct helps them further develop in this constructivist learning environment. It also helps develop real world skills that match the demand for a future work environment. Despite its benefits, the concept of learning to prepare recorded presentations has yet to take root in most EFL oral presentation classrooms.

\section{Methodology}

\subsection{Participants}

Eight intermediate college level EFL classes with a total of 250 students and one beginner college level EFL class with 12 student,s at a private university in South Korea were approached to take part in the research. The language proficiency level of the students was determined by their English language assessment admission exam (an English entrance exam based on TOEIC and administered by an agency outside the university). Intermediate level is students with scores of 401 to 700 points on the test, while beginner level is students with scores of 400 and below. Students were mostly taking all their classes remotely and overall spending less time outside their homes.

Participation was voluntary and therefore out of the 262 students approached, 145 agreed to take part. Participants were from a variety of majors and faculties including general education, fine arts, physical science, and engineering. The class was compulsory for completion of a student's general English requirements prior to graduation. Given the variety of majors and the fact that this a non-major related mandatory course, motivation to succeed in the class is usually mixed. Students were mostly first year, second semester students, but this was not always the case as some were repeating the class or taking it late in their studies to fulfill their graduation requirements.

\subsection{Teaching Method}

The EFL oral presentation class was taught during two 
1.5-hour classes per week over a 15-week period. Due to restrictions on in-person teaching resulting from the prevalence of COVID-19, the university administration determined that this course would be delivered online at the start of the semester and could change to offline if the situation improved during the term. Classes were large, with an average of 33 students per section.

The online lessons were pre-recorded video lectures posted to an internal LMS for students to view. These classes were asynchronous, but students had two weeks to watch the content. There are six units in the textbook plus one introductory unit, and it generally took 2 weeks to complete a chapter. $<$ Table $1>$ is a sample two-week syllabus. The format was repeated for all units of the textbook.

The focus of the lessons was business presentations, organized by an introduction, body and conclusion. Each one centered on topic development, format and outline of the presentation. They also included key phrases and target skills to focus on such as eye contact, posture, gestures, the ability to manage anxiety and the use of voice in projecting and delivering persuasive content and intended meaning. Later in the semester, the online lessons focused on how to include presentation software in their delivery. Lessons also included examples of good and bad oral presentations that were provided by the textbook publisher.

Over the 15-week period, students were required to complete 5 homework presentations ( 1 to 3 minutes in length) and 2 exams (2 to 4 minutes in length). Unit 3 and 6 were used as exam presentations. Taking into consideration the logistical challenges presented by the large class size, it was decided that there would be few added benefits to conducting synchronous remote delivery for student presentations. The only other option was to set student presentations as pre-recorded submissions. This was intended to enhance the constructivist learning environment and to see if it increased motivation to learn, while addressing the associated anxiety that results from live audience activities. Overall student reaction to the recorded assignments would address the research question of whether or not students would actively engage in the experiential learning process.

Each assignment was recorded and uploaded to YouTube by the students for assessment by the teacher. The presentation links were submitted online to the professor for grading using a pre-disclosed rubric. The rubric focused on organization, language and delivery. Students were given time and date deadlines with a short late submission period where points were deducted depending on the tardiness of the submission.

Students were asked to film themselves from the knees up so that an effective presentation posture was used. They were also asked to imagine there was a live audience they were speaking to, so they could simulate eye contact with different segments of the room instead of simply staring directly into the camera. This was because the class textbook was specifically designed for teaching live presentation skills, where eye contact with listeners around the room is a key component of the speech delivery. In

〈Table 1〉 Sample Lesson Plan

\begin{tabular}{|c|c|c|}
\hline Week 1 & Lessons & Resources/ homework \\
\hline $\begin{array}{l}\text { Class } 1 \\
\text { Class } 2\end{array}$ & $\begin{array}{l}\text { Activation of background knowledge and brainstorming ideas. } \\
\text { Outlines, organization of script, openers and closers }\end{array}$ & Textbook, online videos produced by the publisher. \\
\hline Week 2 & Activities & Resources/ homework \\
\hline $\begin{array}{l}\text { Class } 3 \\
\text { Class } 4\end{array}$ & $\begin{array}{l}\text { Presentation skills and tips } \\
\text { First presentation due. }\end{array}$ & $\begin{array}{l}\text { Textbook, online videos produced by the publisher. } \\
\text { Students review class presentations. } \\
\text { Homework: complete a self-reflection assignment on group and } \\
\text { individual performances. }\end{array}$ \\
\hline
\end{tabular}

- Present Yourself 2, second edition, Steven Gershom (intermediate level)

- Present Yourself 1, second edition, Steven Gershom (beginner level) 
an online presentation, it is recommended that students look directly in the camera, but given that we were not sure if the classes were to resume in person later in the semester, students were asked to imagine they are addressing a room full of people. They were also encouraged to use gestures for speaking emphasis. Slide shows were added to their presentation requirements by the second half of the semester. This was to ensure they could interact with technology while maintaining composure during a presentation. Given that the presentations were recorded adding presentation software to the recording created technological hurdles that students were tasked to overcome. These are skills that are necessary to develop in the face of a $4^{\text {th }}$ industrial revolutionary economy, where the reliance on technology outside the classroom is a genuine reality.

Students were permitted to make as many recordings as required before submitting a version they were satisfied with however, to address the lack of public pressure and live audience scrutiny, the submitted videos were shared with the class for a participation assignment, ensuring students were aware the video would be viewed by more than just the professor. During the participation assignment, students were asked to watch the class videos and identify areas where the class was doing well and areas they needed to improve. They were also asked to compare their own presentation skills, relative to their classmates for areas they can improve. This was designed to activate the students' competitiveness and willingness to take the time required to improve. Their responses were submitted online for review and collated for presentation to the class by the professor in the subsequent lessons. While it was thought this could not fully address the anxiety of presenting before a live audience, it did attempt to tackle their motivation to improve.

Students were given individual feedback on their assignments along with their rubric to ensure they understood how and where improvements could be made. In addition, any recurring problems shared by the entire class were addressed in the subsequent online teaching lesson for clarification purposes. It was generally viewed as a problem with instruction that needed addressing more than a problem with the delivery skills of the class.

\subsection{Data Collection}

Information shared in class evaluations, at midterm and the end of the semester were used in this course analysis. Furthermore, due to COVID-19 restrictions on gatherings and social distancing, it was determined best to collect information directly from the students using an online survey method. A Google Form was created and distributed electronically to the students. Participation was voluntary and anonymous so that students would not have the impression participation would impact their final grade. The questionnaire was posted to the online bulletin board for the class two weeks prior to the final exam and remained open until the last day of class. It was made clear that participation was for research purposes only and had no bearing on their grade for the class.

Questions were presented in English and their primary language (Korean) and students were welcome to respond using either. Responses given in Korean were translated to English for this author's analysis. The majority responded using English (118) with the remaining 27 responding in Korean.

The survey presented 4 open-ended questions and included queries on the time students invested in planning, practicing, and delivering presentations as well as which method of presentations they perceived as easier, live audience (offline) or pre-recorded (online) delivery and why.

\subsection{Data Analysis}

The research design, analysis and results are presented from a qualitative perspective. Qualitative research as defined by Creswell (2013, p. 300) "is an inquiry process of understanding based on a distinct methodological approach to inquiry that explores a social or human 
problem." Maxwell (2013, p. viii) writes, “qualitative research is research that is intended to help you better understand (1) the meanings and perspectives of the people you study - seeing the world from their point of view, rather than simply your own; (2) how these perspectives are shaped by, and shape, their physical, social, and cultural contexts; and (3) the specific processes that are involved in maintaining or altering these phenomena and relationships." Using a phenomenology approach based in an ontological philosophy, the researcher attempted to gain insight into the subject matter under investigation through student class feedback, midway through the semester and at the end of term as well as through an online survey using open ended questions delivered at the end of term. Data was collected from several respondents, important reoccurring themes and patterns in the information were identified and categorized, and relationships were uncovered permitting the author to confirm several interconnected learning theories in oral EFL presentation education.

Given that there were social restrictions due to COVID -19 all interaction with subjects took place online. The last section of the questionnaire included an open-ended question where students described what presentation method, live audience or recorded submissions, they perceived was easier and if they preferred it. The answers were explicit in almost all cases ensuring the open-ended questions produced easily identifiable themes as respondents used similar numbers and words to describe their responses. This was confirmed using NVivo software to identify reoccurring themes in the data. Any quantitative data collected from the open-ended questions were coded and analyzed using descriptive statistics such as mean and percentage to also help illustrate patterns that were emerging in the responses and confirm the interconnected learning theories in oral EFL presentation education literature.

\section{Findings and Discussions}

\subsection{Time Spent Preparing a Presentation}

Students were asked to report the time they spent preparing for their recorded presentations. This included brainstorming, writing, and practicing. $<$ Table $2>$ shows that overall, most students, $47 \%$, reported spending 1 to 2 hours preparing for an average presentation. Assignment lengths varied throughout the semester from a 1 to 4 minutes long, but most assignments were around 2 minutes in length. Interestingly, $44 \%$ of the students reported spending more than 2 hours preparing their presentations with more than half reporting spending more than 3 hours preparing the assignment. One student wrote, "It takes more than 1 hour, less than 2 hours if you mean the time to compose the presentation. It takes 2 to 3 hours to practice the presentation before recording" (Student 54).

〈Table 2〉 Time spent preparing (Prior to Recording)

\begin{tabular}{l|c|c}
\multicolumn{1}{c|}{ Time } & \# of Students & $\%$ of Students \\
\hline Less than 1 hour & 13 & .09 \\
$1-2$ hours & 68 & .47 \\
$2-3$ hours & 30 & .21 \\
$3+$ hours & 34 & .23 \\
\hline Total & 145 & 1.00 \\
\hline
\end{tabular}

These numbers are unsurprising as King (2002) mentioned, oral presentations are a student-centred activity with much of the learning landing on the laps of the class instead of the teacher. There is no data available to compare this to the time spent preparing for live audience presentations, however, the numbers seem consistent with the author's previous experience of student feedback for offline classes.

\subsection{Time Spent Recording a Presentation}

Students were asked to report how long it took them to record their presentation. The responses in $<$ Table $3>$ show they spent a similar amount of time recording their 
presentations as they did preparing to record their presentations. $55 \%$ of respondents reported spending 1 to 2 hours recording an average presentation. 77\% reported spending up to two hours recording. Interestingly, nearly one quarter of the students responding, $23 \%$, said they spent a minimum of 2 hours recording their presentations.

〈Table 3〉 Time Spent Recording

\begin{tabular}{l|c|c}
\multicolumn{1}{c|}{ Time } & \# of Students & \% of Students \\
\hline Less than 1 hour & 32 & .22 \\
$1-2$ hours & 80 & .55 \\
$2-3$ hours & 13 & .09 \\
$3+$ hours & 20 & .14 \\
\hline Total & 145 & 1.00 \\
\hline
\end{tabular}

Overall, the time spent recording, where students perfected their presentations, was anywhere from less than an hour to over 3 hours. Of that group two reported spending up to 5 hours and one spent up to 7 hours. Over a 15-week class period, these numbers represent a significant amount of time added to their homework schedule from that of a live audience presentation class. This was a considerable amount of extra work for EFL students that would otherwise not be present in an offline classroom environment, where students simply show up and present. There is no time allotted for repeat presentations or restarts that address the things students feel did not go right in their presentation. This confirms the concerns raised by students about the significant amount of work required to complete each recorded assignment for the online class. Student 11 said, "Online [recorded] presentations take a lot of time and effort, but with enough time and effort, you can produce satisfactory results to some extent. However, live presentations are burdensome in that mistakes are irreversible." The recorded presentation format was clearly an experiential learning activity where students took the time they required to achieving their desired result. It is important to understand how this time was spent. The next question addresses this information.

\subsection{Number of Recording Attempts}

Students were asked how many recording attempts were made during this extra time period before settling on one they were satisfied to submit. $<$ Table $4>$ reveals that $54 \%$ of respondents said they made on average 10-30 recordings for each assignment. While a total of $21 \%$ recorded 31 to over 100 versions.

\begin{tabular}{l|c|c}
\multicolumn{3}{|c}{$\langle$ Table 4〉 Number of Recordings } \\
\hline \multicolumn{1}{|c|}{ Recordings } & \# of students & $\%$ of students \\
\hline Less than 10 & 35 & .24 \\
$10-30$ & 78 & .54 \\
$31-50$ & 20 & .14 \\
$51-100$ & 6 & .04 \\
More than 100 & 5 & .03 \\
Did not specify & 1 & $>.01$ \\
\hline Total & 145 & 1.00 \\
\hline
\end{tabular}

There could be several reasons for their re-takes. The first could be simply that they forgot what they were going to say. Students were permitted note cards to refer to if they forgot what they intended to say, but access was limited to not more than $10 \%$ of their presentation. If students felt they relied on their notes too much, they may have opted to re-record. "Because I can spend time to prepare the speech, the quality of presentation is better than live" (Student 128).

A second reason for a re-take could be a technical difficulty. Students were recording from home using their own equipment and it is possible they could have struggled with the technology they had available requiring a re-take. Student 80 said, "I think who doesn't have a computer or a laptop cannot prepare a presentation well than others who has." While student 2 said, "some of us has Bluetooth mouse, and some of us hasn't. It's quite huge in presentation." Learning to work through technological difficulties is a good skill set for the modern work environment, where many interactions take place online and it adds to the student's learning experience.

The final reason for re-takes is the student's self-critique 
of their performance. In Kolb's stages of experiential learning, students produce, reflect and self-correct. Students were given a rubric for their assignments detailing the areas they would be graded upon. This tool could have been used by students to self-assess their recorded performances. They were graded on language (including word choice), voice (including intonation pauses and word stress) posture and gestures, organization of ideas, eye contact, and their ability to manage their own anxiety. Upon review of their output, any of these factors could have provided reason for the students to re-try their recording. Student number 2 said they took up to 2 hours recording their videos, making anywhere from 25-30 attempts. They said this method of delivery for presentations was preferred because, "I can record it several times until I like it."

Overall, the data collected proved the recorded presentation delivery environment encouraged students to take their role of the self-directed learner seriously. They invested a significant amount of time on their own during their learning experience. The ability to see their output, created a learning environment for students that relied on their own self-analysis and skills development. It is clear that while preparing the videos, students were practicing Kolb's theory of experiential learning where they were not merely delivering the presentations, as they would before a live audience, they were actively engaging in production, reflection of their output, and self- correction

The additional homework time spent on self-correction in the re-recording process was a critical part of their language learning experience. Oral presentations are a student-centered learning activity designed to improve communicative competence. As King (2002) argued, the benefit of recording a presentation is that students can watch and listen to themselves, and self correct to deliver the best possible result, further enhancing their own skills development. This constructivist form of learning helps students create new knowledge.

During live audience presentations, students are conscious of making mistakes and according to researchers (Fook et al., 2011; Liu, 2007; \& Warden \& Lin, 2004) this hinders their ability to self-improve. Removing the pressure to be perfect by allowing students to re-record their presentations encouraged them to work longer at developing their skills and it is clear from their responses that they took advantage of this opportunity. Student number 4 said, "It takes me two days to submit the video. It's hard, my legs hurt, and my throat is swollen. The online [recorded] presentation is fair because it reflects my efforts." Student number 7 said, "a person who has prepared a lot can make a high-quality video without mistakes."

Live audience presentations offer fewer chances for students to fully self-reflect prior or post delivery, while recorded presentations enable the student to hear their own voice and critique their own delivery and composure, thereby improving their communicative competence. This self-reflection enables students to be more self aware and provides learning opportunities to adjust where necessary. In fact, one student said they found recorded presentations easier because, "I can practice with my video" (Student 103). This type of reflective learning can provide experiences that are not normally available in the live audience presentation environment.

\subsection{Recorded vs. Live Presentations}

Students were asked which method of presentation they believe to be easier, pre-recorded submissions in the online class or live audience presentations in the offline class. $<$ Table $5>$ shows that an overwhelming number of respondents, $84 \%$, perceived recorded presentations as easier. This was surprising despite the workload being

$\langle$ Table 5〉 Overview of Student Perceptions of Easiness in Online vs. Offline Presentations

\begin{tabular}{l|c|c} 
Which method do you perceive as easier online & $\begin{array}{c}\% \text { of } \\
\text { (recorded) or offline (live audience) presentations? }\end{array}$ \\
students
\end{tabular}


nearly double that of a live audience presentation, if we account for time spent recording.

It was clear from the responses that despite the additional workload, the students found recorded presentations for the online class easier. While it is impossible to say for sure if students would have felt the same way had they had a chance to deliver a live audience presentation to make a fair assessment, it was clear from the responses that they understood the pressures associated with live audience presentations. While the workload was increased due to the added element of making a recording, the self-reflection opportunities imparted by the method of delivery encouraged students to work harder to overcome their perceived weaknesses and/or mistakes. One student said,

The easier one is online [recorded], but I think it's also online that takes more effort. Live [audience presentation] is over if I make a mistake once, but I don't have much effort because the presentation ends at once. Since online has the advantage of being able to film again, the professor knows that there are many more chances to film a more perfect video, so I think we should continue until the perfect video comes out (Student 54).

One student said recorded presentations were harder, but better because they provided more time for study. "Live [audience] would be easier, but online is better. Because I need much time for online, but that is a process for study, not a waste of time" (Student 49).

Fostering motivation to improve, a key component of language acquisition, is often challenging in a class that is a required element for graduation for all majors. Students from some departments such as performing or creative arts for instance, may see little value in developing the skills required to do well in an oral EFL presentation class. However, the study reveals that only $9 \%$ of all students who participated in the survey spent less than an hour preparing for their presentations while $22 \%$ of the students spent less than an hour recording their presentations. These results indicate the course design might have been a factor that helped motivate students to try harder in the class. This could also be because those with low confidence in their skills recognized they had a better chance to succeed in class if they invested the added effort into their recordings. However, this is also the reason not everyone preferred recorded presentations. One student said the ability to re-record unfairly levels the playing field. "Live presentations make it fair for everyone, while online (recorded) presentations give everyone a chance to succeed" (Student 85).

It can be argued that by removing room for mistakes, recorded presentations do not reflect one's true command of the target language by failing to reveal the student's preparedness and how easily they can recover from any delivery errors in a live audience environment. However, it is not only those less motivated to learn the target language that benefits from recorded presentations. Some students suffer from presentation anxiety regardless of their preparedness and command of the language. By removing the anxiety associated with a live delivery, replacing it with the ability to re-record, these students have a greater chance to succeed. One respondent said the stress of public speaking increases the number of mistakes they make during a live audience presentation.

I think the online [class] presentation method is easier. Live [audience] presentations can collapse no matter how perfectly I practice, but online presentations can be recorded at any time until I like them, so I can take it easy (Student 35).

Another student said, "I think online [class] presentations are easier. This is because live [audience] presentations depend on one's condition at the time" (Student 45). This supports King's (2002) concerns that the anxiety had a significant impact on a student's ability to delivery an effective presentation that adequately reflects their skills. 


\subsection{Justification for Response}

When asked to explain the reason for their opinion, this open-ended question produced surprisingly similar responses from the participants. Reoccurring themes were easily identifiable as a result of an analysis of the replies. Some students offered one reason, but most offered multiple reason. In $<$ Table $6>$ you can see that the primary reason reported for believing videoed presentations were easier was the ability to re-record an unsatisfactory presentation. $57 \%$ of those preferring this online class format for oral presentations cited this as a reason.

The second most popular response was the lack of live audience pressure. $26 \%$ of respondents reported this as a reason for the online class recorded presentation submissions being easier. The pressure of a live audience causes anxiety for some students. By removing this factor, students were confident despite the added workload, that recorded presentations were easier.

〈Table 6〉 Reasons Why the Online Class Presentations Are Easier

\begin{tabular}{l|c|c}
\multicolumn{1}{|c|}{ Reason } & \# of Students & $\%$ of Students \\
Ability to re-record & 70 & .57 \\
No live audience pressure & 32 & .26 \\
COVID 19 & 3 & .03 \\
Travel time to university & 3 & .03 \\
\hline
\end{tabular}

These results are similar to those found in the 2012 study by Saidalvi and Mansor where they reported in the constructivist learning environment created by the online class nearly $96 \%$ of students preferred recorded deliveries of oral presentations as they eliminated their fear of presenting before a live audience another $96 \%$ preferred recorded presentations because they felt they had a lot of opportunities to practice their speeches. $17 \%$ of respondents choosing this method of delivery did not offer any reason for their preferences.

Students who found offline/live audience presentations easier are described in $\langle$ Table $7>$. Their total number was limited to 13 or $9 \%$ of respondents and their reasons varied with $23 \%$ responding that it was less work overall and another $23 \%$ not offering up a specific reason. This finding could be a result of the class being a required course for graduation. Students may be taking the course to check the box rather than to actually improve. One student of the three students who said live audience presentations were easier because it was less work wrote, simply "It's over at once" (Student 82). While another wrote, "I think live presentations are easier than online [recorded] presentations. Because online presentations take too much time" (Student 114).

$\langle$ Table 7〉 Reasons Why Offline/Live Presentations Are Easier

\begin{tabular}{l|c|c}
\multicolumn{1}{|c|}{ Reason } & \# of Students & \% of Students \\
Less work (1 and done) & 3 & .23 \\
Easier/fair to grade & 2 & .15 \\
Easier to understand speaker & 1 & .08 \\
Awkward in Video & 1 & .08 \\
Camera problems & 1 & .08 \\
Communicate with Professor & 1 & .08 \\
Online can be released publicly & 1 & .08 \\
\hline
\end{tabular}

One of the 10 students had no preference, saw the benefits of both methods of oral presentation delivery citing the ability to re-record as a reason for preferring the online classes presentation method, but also acknowledged the ability to handle mistakes in a live audience environment as a benefit of live presentations.

Both have their own merits. Online [recorded] presentations should continue to re-record if I make mistakes. But I can record a perfect presentation video. Live [audience] presentations are irreversible in case of mistakes. However, mistakes can be humorously passed on by the speaker's wit. And I can make presentations that communicate directly with the audience (Student 68).

Another student understood that both methods were just as difficult. They wrote, 'I don't think there is anything easier" (Student 145). 


\section{Conclusions, Implications and Limitations}

In this study, the constructivist design of the oral EFL presentation classroom was assessed in terms of its affect on experiential learning and its overall impact on the student's learning experience. The research revealed that most students (68\%) spent one to three hours preparing for their recorded presentations. For most of the class (54\%), each recorded presentation took 10-30 attempts, before the student was able to settle on one they were satisfied to submit for grading. This process took $55 \%$ of students one to two hours to complete. Given that they had 7 presentations to deliver throughout the 15-week semester, it was clear they invested a significantly higher amount of time in their studies for this course than they would have spent on the class if they were presenting before a live audience. The data collected proves the use of recorded presentations engendered increased application of the experiential learning cycle. This can be seen in the amount of time spent on recordings and the number of recording attempts made before settling on one for submission. In addition, the research revealed that despite the extra workload, an overwhelming majority of students found recorded asynchronous presentation submissions easier and the predominate reason was their ability to re-record with the second most popular reason being unsurprisingly, the lack of audience related stress that comes with delivering a presentation live.

This author began this investigation with the impression that an EFL oral presentation class conducted online would provide nothing more than lip service to the ultimate goal of the class; An ability to demonstrate your command of the target language under pressure of the gazing eyes of your peers. However, it is clear from the results of this investigation that while the live audience atmosphere was impossible to fully recreate, students still benefitted from the class, just in a different way. Overall, they invested a lot more time preparing and producing each recorded presentation and the act of reviewing their video clips offered a unique opportunity to self-reflect which is often missing from offline presentation classes. When delivering oral presentation before a live audience, students only 'think' they know how they performed, but by watching themselves on screen, they 'know' the areas they need to improve, and they are afforded the opportunity to self-correct by re-recording. This was clearly an exercise in experiential learning.

In addition, by removing the fear and anxiety that we know exists in the synchronous presentation delivery process, students were motivated to develop their skills as evidenced by the lengthy reported hours invested in their assignments. Motivation to improve in this class is not normally shared by all students registered in the course, since it is a mandatory class that may seem irrelevant for students of some majors. One possible reason for the increased time invested in the assignments could have been the lockdown environment, however no student mentioned this in their comments. Nevertheless, the ability to self-correct seems to have engaged more students in the constructivist learning experience. Selfdirected learning was heightened in this recorded homework assignment environment. Students were more acutely aware of any delivery shortcomings by seeing it in practice and were able to record their assignments again, addressing their perceived problem areas. This tangible practice is not otherwise available when student assignments are to deliver the presentation before a live audience. Under these circumstances, students may be asked to reflect on their performance after the fact, and usually without any recording to reference. Moreover, using recorded assignments, once they are graded and returned, students can review their videos and compare them with their awarded results. Armed with this information, they could pose any questions to the professor that would clarify areas they need to do to improve, further enhancing their constructivist learning experience.

Being able to problem solve and work independently is also a skill set required in the workplace of the $4^{\text {th }}$ industrial economy. Speeches are no longer being delivered 
solely in the live audience domain. Adapting the delivery of speeches to an asynchronous environment, where recording and uploading professional looking presentation videos to the Internet are practiced, have become competencies that are useful for the 21 st century work environment. The skill set helps students become more competitive in the job market. Laurel Farrer of Forbes Magazine suggests asynchronous meetings are a reality for future businesses (2020). Knowing how to navigate through the production of fruitful input in this environment is a skill that will no doubt help students in their future careers.

While the results of time spent on any given assignment were surprising and the benefits for improved communicative competence clear, it remains to be seen what role recorded presentations will play in the teaching of oral presentations in the EFL learning environment. This author would argue that delivering oral EFL presentations through a recorded format should be considered a valid part of modern curriculum. It helps promote experiential learning and increases confidence in speakers and develops skills required for the $4^{\text {th }}$ Industrial Revolution.

While it is true that none of these very real benefits replaces delivering a presentation before a live audience, but more importantly, they should not have to. There is room for both. Recorded presentations should not be discounted as meaningless when designing the curriculum for future offline classes. This author would argue it is essential to educate students on how to present both synchronously and asynchronously. In addition, the benefits of recording and watching your own presentation delivery and comparing your skills to an ideal outcome is arguably as imperative for improving delivery as performing under pressure of a live audience. It also provides the necessary incentives for all students to self-reflect and invest more time and effort into perfecting their presentation delivery. While we cannot say for sure the students performed better than they would have before a live audience, it is clear the constructivists classroom environment motivated them to work harder on their recordings and they preferred it.

Despite these conclusions, there are still some limitations to the research. Given that the time spent, and number of recordings were self-reported, students might have under or even over exaggerated their numbers. The amount of time spent on their assignments could have also been influenced by the fact that students were a "captive audience" resulting from their socially confined Covid-19 environment. Finally, the diversity of majors may have also impacted the results because different majors may have different levels of motivation to do well in an oral EFL presentation class. It would be interesting for future research to compare the learning outcomes of students presenting before a live audience of similar majors and English proficiency levels to those in online classes with recorded assignment submissions, in order to see if there is a marked difference in student performance.

\section{References}

Al-Hebaish, S. M.(2012). "The Correlation between General Self-Confidence and Academic Achievement in the Oral Presentation Course", Theory and Practice in Language Studies 2(1), 60-65. doi:10.4304/tpls.2.1.60-65

Al-Issa, A. S.(2006). "Ideologies Governing Teaching the Language Skills in the Omani ELT System", Journal of Language and Learning 4(2), 218-231.

Al-Issa, A. S., \& Al-Qubtan, R.(2010). "Taking the Floor: Oral Presentations in EFL Classrooms", TESOL Journal 1(2), 227-246. doi: $10.5054 / \mathrm{tj} .2010 .220425$

Böhme, K.(2009). "Web-based rhetorical training - a virtual impossibility? Problems and perspectives of improving public speaking skills in virtual learning environments", Journal of Education, Informatics, and Cybernetics 1(1), 1-6. Retrieved from http://www.journaleic.com/article/dow nload/3460/2595 http://www.iiis.org/CDs2008/CD2008SC I/EISTA2008/PapersPdf/E445EY.pdf

Creswell, J. W.(2013). Qualitative Inquiry \& Research Design: Choosing among five approaches, Sage Publications.

Farrer, L.(2020, December 10). "The art of asynchronous: optimizing efficiency in remote teams", Forbes Magazine, https://www. forbes.com/sites/laurelfarrer/2020/12/10/the-art-of-asynch ronous-optimizing-efficiency-in-remote-teams/?sh $=4$ ee 50 $7 \mathrm{e} 4747 \mathrm{c}$

Fook, C. Y., Sidhu, G. K., Rani, N., \& Aziz, N. A.(2011). 
"Analyzing Factors Associated with Students' Oral Test Performance", The International Journal of Educational and Psychological Assessment 9(1), 27-47. ISSN 2094-0734.

Gardner, R.(2007). "Motivation and Second Language Acquisition", Porta Linguaram 8, 9-20.

Katchen, J. E.(1991). "Using the Video Camera to Improve Speaking and Performance Skills", In M. C. Yang (Ed.), Papers from the eighth conference on English language teaching and learning in the Republic of China (pp. 531-540), Crane Publishing Co., Ltd. http://mx.nthu.edu.tw/ katchen/ professional/Using\%20the\%20video\%20camera.htm

King, J.(2002). "Preparing EFL learners for oral presentations", Journal of Humanistic Studies 4, 401-418.

Kolb, D.(1984). Experiential Learning: Experience as the Source of Learning and Development, Upper Saddle River: Prentice Hall.

Liu, M.(2007). "Chinese students' motivation to learn English at the tertiary level", Asian EFL Journal 9(1), 126-146. Retrieved from http://www.asian-efl-journal.com/March_2 007_EBook.pdf?q=current-issue-volume-15-number-9-pu blished-on-3-march-2005\#page $=126$

Maxwell, J. A.(2013). Qualitative Research Design: An interactive approach, Sage Publications.

McLsmieod, S.(2017). "Kolb's Learning Styles and Experiential Learning Cycle", Simply Psychology, https://www.simplyps ychology.org/learning-kolb.html

Mohd Ali, S., \& Ismail, H.(2020). "Language and Education in the Midst of the 4IR Challenges", International Journal of Language Education and Applied Linguistics 10(1), 5-7. doi:https://doi.org/10.15282/ijleal.v10.4606

Saidalvi, A., \& Mansor, W. F. A. W.(2012). "Utilising Constructivists Learning Environment (CLE) in Designing an Online Help for Students in Acquiring Public Speaking Skills", Procedia - Social and Behavioral Sciences 66, 518-528.

Smirnova, N. V., \& Nuzha, I. V.(2013). "Improving Undergraduate Sociology Students' Presentation Skills through Reflective Learning in an Online Learning Environment", MERLOT Journal of Online Learning and Teaching 9(3), 406-417.

Spöttl, G., \& Windelband, L.(2021). "The $4^{\text {th }}$ industrial revolution - its impact on vocational skills", Journal of Education and Work 34(1), 29-52. doi:10.1080/13639080.2020.1858230

Suraini, M. A., \& Habibah, I.(2020). "Language and Education in the Midst of the 4IR Challenges", International Journal of Language Education and Applied Linguistics 10(1), 5-7. doi:https://doi.org/10.15282/ijleal.v10.4606

Warden, C. A., \& Lin, H. J.(2004). "Different attitudes among non-English major EFL students", The Internet TESL Journal 4(10). Retrieved from http://iteslj.org/Articles/Warden-Diff erence/

Živković, S.(2014). "The Importance of Oral Presentations for University Students", Mediterranean Journal of Social Sciences 15(19), 468-475. doi:10.5901/mjss.2014.v5n19p468

Živković, S., \& Stojkoviý, N.(2013). "To Modernize or Not to Modernize - There is No Question", Academic Journal of Interdisciplinary Studies 2(11), 70-76. doi:10.5901/ajis.2 013.v2n11p70 


\section{Appendix 1}

\section{Survey Questions}

1. How much time do you spend preparing for your online presentation? (Not including recording.) 온라인 프리젠테이션을 준비하는 데 시간이 얼마나 걸리나요? (녹화는 포함되지 않습니다.)

2. How much time do you spend recording?

녹음하는데 얼마나 많은 시간을 쓰나요?

3. How many times do you record your video before turning one in?

동영상을 제출하기 전에 동영상을 몇 번 녹화합니까?

4. Which method of presentations do you perceive as being easier, online presentations or live and why? 온라인 프레젠테이션과 라이브 프레젠테이션 중 어떤 프레젠테이션 방법이 더 쉽다고 생각합니까? 그 이유는 무엇입니까? 


\section{학생 제작 발표 영상을 통한 구두 EFL 발표 수업에서의 경험적 학습 형성}

\section{나탈리 할레만스 \\ 단국대학교 부교수}

\section{초록}

본 질적 연구는 수업 내용 전달 및 발표 과제, 시험이 모두 녹화 형태로 온라인 교실에의 업로드를 통해 제출되는 온라인 구두 발표 수업에서의 학생들의 학습 경험을 살펴본다. 본 연구의 목적은 콥(Kolb)의 경험적 학습 이론의 영향을 받은 구성주의 수업 형식이 학생들의 동기 부여에 미치는 영향을 탐구하고 해당 경험에서 도출되는 긍정적인 혹은 부정적인 결과를 모두 기록하는 것이다. 수집된 데이터에 따르면 대부분의 학생들은 발표 준비에 1-2시간을 할애하고 추가적으로 녹화하는데 1-2시간 을 들이는 것으로 나타났다. 녹화에 추가적으로 소요된 시간은 녹화 형태의 과제 제출이 학생들의 개선을 위한 동기부여에 직접적으로 영향을 끼쳤다는 사실을 암시한다. 또한 자신을 점검하고 실수를 교정할 기회를 주며 청중 앞에서 발표하는 것에 대한 불안감에서 해방될 수 있다는 이유로 대부분의 학생들은 사전 녹화 제출을 선호하였다. 많은 학자들이 발표 기량이 흔히 쓰이는 실제 청중 앞에서의 구두 발표가 최고의 연습 방법이라고 믿고 있는 반면 코로나 이후의 업무 환경에서는 더 많은 사람들이 원격 근무를 하여 온라인 구두 발표 능력이 더 중요해질 것으로 예상된다. 비동기(asynchronous) 발표에 필요한 능력을 배양함으로써 학생들은 구직 시장에서 더 큰 경쟁력을 갖게 될 것으로 사료된다.

주제어: 온라인 교육, 구두 $\mathrm{EFL}$ 발표, 경험적 학습, 동기 부여, 성찰적 학습 